\title{
Lead toxicity in Saccharomyces cerevisiae
}

\author{
Maarten Van der Heggen • Sara Martins • \\ Gisela Flores • Eduardo V. Soares
}

Received: 21 June 2010 /Revised: 19 July 2010 /Accepted: 24 July 2010 /Published online: 1 September 2010

(C) Springer-Verlag 2010

\begin{abstract}
The effect of $\mathrm{Pb}$ on Sacharomyces cerevisiae cell structure and function was examined. Membrane integrity was assessed by the release of UV-absorbing compounds and by the intracellular $\mathrm{K}^{+}$efflux. No leakage of $\mathrm{UV}_{260}$-absorbing compounds or loss of $\mathrm{K}^{+}$were observed in $\mathrm{Pb}$ (until $1,000 \mu \mathrm{mol} / \mathrm{l}$ ) treated cells up to $30 \mathrm{~min}$; these results suggest that plasma membrane seems not to be the immediate and primary target of $\mathrm{Pb}$ toxicity. The effect of $\mathrm{Pb}$ on yeast metabolism was examined using the fluorescent probe FUN-1 and compared with the ability to reproduce, evaluated by colony-forming units counting. The exposition of yeast cells, during $60 \mathrm{~min}$ to $1,000 \mu \mathrm{mol} / \mathrm{l} \mathrm{Pb}$, induces a decrease in the ability to process FUN-1 although the cells retain its proliferation capacity. A more prolonged contact time $(120 \mathrm{~min})$ of yeast cells with $\mathrm{Pb}$ induces a marked $(>50 \%)$ loss of yeast cells metabolic activity and replication competence through a mechanism which most likely requires protein synthesis.
\end{abstract}

M. Van der Heggen · S. Martins · G. Flores · E. V. Soares $(\varangle)$ Bioengineering Laboratory, Chemical Engineering Department, Superior Institute of Engineering from Porto Polytechnic Institute, Rua Dr António Bernardino de Almeida, 431, 4200-072 Porto, Portugal

e-mail: evs@isep.ipp.pt

M. Van der Heggen

Department of Industrial Engineering, KaHo St.-Lieven,

Gebroeders Desmetstraat 1,

9000 Ghent, Belgium

E. V. Soares

IBB-Institute for Biotechnology and Bioengineering, Centre for Biological Engineering, Universidade do Minho,

Campus de Gualtar 4710-057,

Braga, Portugal
Keywords Cell membrane $\cdot$ FUN-1 $\cdot$ Lead $\cdot$ Metal toxicity Yeast viability

\section{Introduction}

Heavy metals are widely used in industrial processes and can be released in the environment, which causes harmful effects on ecosystems and public health. In the case of $\mathrm{Pb}$, this metal occurs in the environment as a consequence of the natural weathering process of rocks and mainly due to human activities. Several environmental regulations have been proposed in USA and European Union in order to eliminate or reduce the use of $\mathrm{Pb}$ namely in gasoline addictives, paints, solders and water systems. At the present, examples of $\mathrm{Pb}$ applications are as follows: production of accumulators and lead-acid batteries used in the cars, colouring element in ceramic glazes, polyvinyl chloride plastic, bullets and in radiation shield. Thus, it is not surprising that the production and consumption of $\mathrm{Pb}$ is increasing worldwide; in 2009, the total annual production was about 8.8 million tonnes (International Lead and Zinc Study Group, http://www.ilzsg.org/static/statistics.aspx).

In opposition to $\mathrm{Cu}$ and $\mathrm{Zn}$, which are essential metals for optimal growth of cells, although may also be toxic in certain conditions, $\mathrm{Pb}, \mathrm{Cd}$ and $\mathrm{Hg}$ have no known biological roles (Gadd 1993). Lead poisoning was documented in ancient Greece and China and has been linked to the fall of the Roman Empire (Gilfillan 1965). In humans, $\mathrm{Pb}$ can cause blood and brain disorders. It is accumulated in "soft tissues" and bone over time; it remains in a semipermanent reservoir and can be released long term after the initial absorption (ATSDR 2007). Pb is considered as a priority pollutant by the US Environmental Protection Agency (US-EPA 2006). 
Yeast cells, particularly Saccharomyces cerevisiae, are a suitable model for studying $\mathrm{Pb}$ toxic effects. The yeast $S$. cerevisiae is a eukaryote cell that can be easily manipulated and has the genome completely sequenced (Goffeau et al. 1996). It is known that $\mathrm{Pb}$ reduce viability (Suh et al. 1999; Soares et al. 2002; Soares et al. 2003), cell growth, DNA/ RNA ratio and impair ammonium assimilation in yeast cells (Chen and Wang 2007).

In this work, the effect of $\mathrm{Pb}$ on yeast membrane integrity (given by the efflux of $\mathrm{K}^{+}$and the release of UVabsorbing compounds) and metabolic activity (evaluated by the ability to process the fluorescent probe FUN-1) was studied. Using a kinetic approach, the loss of metabolic activity induced by $\mathrm{Pb}$ was compared with the loss of proliferation capacity, assessed by the classical plate count technique. The role of protein synthesis in $\mathrm{Pb}$-induced toxicity was also studied.

\section{Materials and methods}

Strain, media and culture conditions

In this work, the brewing strain of $S$. cerevisiae National Collection of Yeast Culture (NCYC) 1214 was used. The strain was routinely maintained at $4{ }^{\circ} \mathrm{C}$ on YEPD agar slants $(10 \mathrm{~g} / 1$ yeast extract, $20 \mathrm{~g} / 1$ peptone, $20 \mathrm{~g} / 1$ glucose and $20 \mathrm{~g} / \mathrm{l}$ agar).

Pre-cultures were prepared in $10 \mathrm{ml}$ of YEPD broth in $100-\mathrm{ml}$ Erlenmeyer flasks. Cells were incubated at $25^{\circ} \mathrm{C}$ on an orbital shaker Sanyo Gallenkamp IOC 400 (West Sussex, UK), at $150 \mathrm{rpm}$, during $24 \mathrm{~h}$.

Cultures were obtained by inoculating $40 \mathrm{ml}$ of YEPD broth, in $100 \mathrm{ml}$ Erlenmeyer flasks, with $1 \mathrm{ml}$ of preculture. The flasks containing the culture were incubated under the same conditions as the pre-culture. The time of incubation was $16 \mathrm{~h}$, which corresponds to the end of the exponential respiro-fermentative growth phase/beginning of the diauxic lag phase (data not shown).

Preparation of cell suspensions

After growth, cells were harvested by centrifugation $(2,000 \times g$, $5 \mathrm{~min}$ ) and washed twice with $30 \mathrm{mmol} / \mathrm{l}$ ethylenediaminetetraacetic acid (EDTA) solution (Merck, Darmstadt, Germany). Subsequently, cells were washed twice with deionised water and resuspended in 2-( $N$-morpholino) ethanesulfonic acid (MES) $\mathrm{pH}$ buffer (Sigma-Aldrich, St. Louis, MO, USA) $10 \mathrm{mmol} / \mathrm{l}$, at $\mathrm{pH} 6.0$, with $2 \%(w / v)$ of glucose at approximately $1 \times 10^{7}$ cells $/ \mathrm{ml}$. MES is a suitable $\mathrm{pH}$ buffer for heavy metal toxicity studies because it does not complex with several metal ions, such as $\mathrm{Cd}, \mathrm{Cu}, \mathrm{Pb}$ and $\mathrm{Zn}$ (Soares et al. 1999a; Soares et al. 1999b); in addition, yeast cells maintain viability, and no detectable amount of protein or inorganic phosphate is observed in the filtrates when cells are incubated in this buffer for $48 \mathrm{~h}$ (Soares et al. 2000).

Cells concentration was determined spectrophotometrically (Unicam, Helios $\gamma$ ) at $600 \mathrm{~nm}$ after appropriate dilution of the samples in EDTA solution $(30 \mathrm{mmol} / \mathrm{l})$ to prevent cell aggregation. Calibration curves (absorbance versus number of cells) were previously made.

\section{Contact of yeast cells with $\mathrm{Pb}$}

Cell suspensions (40 ml) containing $1 \times 10^{7}$ cells $/ \mathrm{ml}$, in $10 \mathrm{mmol} / 1$ MES buffer (pH 6.0$)$ with $2 \%(w / v)$ of glucose and the appropriate volume of $\mathrm{Pb}$ solution $\left(\mathrm{Pb}\left(\mathrm{NO}_{3}\right)_{2}\right)$ from a stock standard solution of $1 \mathrm{~g} / 1$ (Merck, Darmstadt, Germany) were shaken in 100-ml Erlenmeyer flasks at $150 \mathrm{rpm}$, in an orbital shaker at $25^{\circ} \mathrm{C}$.

To study the effect of protein inhibition, $25 \mu \mathrm{g} / \mathrm{ml}$ of cycloheximide (Cyh) (Sigma) was added to the cell suspensions $\left(1 \times 10^{7}\right.$ cells $\left./ \mathrm{ml}\right)$, at the same time of $\mathrm{Pb}$ solution and under the same conditions described above.

Leakage of $\mathrm{UV}_{260}$-absorbing materials

At defined intervals of time, $4 \mathrm{ml}$ of cell suspension treated with each metal was filtered through a $0.45-\mu \mathrm{m}$ pore-size filter (Advantec, Japan). Optical density at $260 \mathrm{~nm}$ was determined in the filtrates of cell suspensions; buffer solution with the same metal concentration was used as a blank.

\section{Measurement of $\mathrm{K}^{+}$efflux}

Cell suspensions $(20 \mathrm{ml})$ containing $1 \times 10^{7} \mathrm{cells} / \mathrm{ml}$, in $10 \mathrm{mmol} / 1 \mathrm{MES}$ buffer (pH 6.0) with $2 \%(w / v)$ of glucose and $50 \mu \mathrm{mol} / 1 \mathrm{KCl}$, were incubated at $25^{\circ} \mathrm{C}$, with a magnetic stirring, $5 \mathrm{~min}$ prior to the addition of the metals or water (control). Measurement of $\mathrm{K}^{+}$efflux was carried out using a potassium combined electrode (Phoenix Electrode Co.) connected to Orion $420 \mathrm{~A} \mathrm{pH} / \mathrm{mV}$ metre (Orion, Boston, MA, USA). $\mathrm{K}^{+}$-selective electrode was calibrated using known additions of $\mathrm{KCl}$.

Assessment of metabolic activity (staining with FUN-1)

Prior or after contact with $\mathrm{Pb}$, cells were washed with deionised water and with $10 \mathrm{mmol} / \mathrm{l}$ 4-(2-hydroxyethyl)piperazine-1ethanesulfonic acid (HEPES) (Sigma-Aldrich, St. Louis, MO, USA), $\mathrm{pH} 7.2$, containing $2 \%(w / v)$ glucose; finally, cells were resuspended in HEPES buffer, $\mathrm{pH} 7.2$, with $2 \%(w / v)$ glucose at $1 \times 10^{7}$ cells $/ \mathrm{ml}$. FUN-1 (Molecular Probes, Invitrogen, CA, USA) was added to a final concentration of $16 \mu \mathrm{mol} / 1$ from a working solution of $200 \mu \mathrm{mol} / \mathrm{l}$; FUN-1 working solution was prepared, before use, by diluting a stock solution of 
$10 \mathrm{mmol} / \mathrm{l}$ in HEPES buffer, $\mathrm{pH} 7.2$, with $2 \%(w / v)$ glucose. The cell suspension was incubated in the dark, at $25^{\circ} \mathrm{C}$, during $30 \mathrm{~min}$. Then, cells were examined using a Leica DLMB epifluorescence microscope (Leica Microsytems, Wetzlar GmbH, Germany) equipped with a HBO-100 mercury lamp and a filter set I3 (excitation filter BP 450490, dichromatic mirror 510 and suppression filter LP 515) from Leica. For each sample, at least 400 cells were scored in randomly selected microscope fields.

Images were acquired with a Leica DC 300F camera (Leica Microsystems, Heerbrugg, Switzerland) using a N plan $\times 100$ objective; the images were processed using Leica IM 50-Image manager software.

\section{Evaluation of cell proliferation capacity}

Before and after the addition of the metal, samples $(100 \mu l$; two replicates) were taken at defined intervals of time, serially diluted with sterile deionised water and plated on YEPD agar (two replicates of 100-200 $\mu \mathrm{l}$ from convenient dilutions). After 3-4 days of incubation at $25^{\circ} \mathrm{C}$, the colonies were counted. Original cell suspensions had viability higher than $99 \%$.

\section{Results}

Action on membrane integrity

Yeast cell wall is a porous matrix, which allows the passage of most of ions and molecules of molecular mass

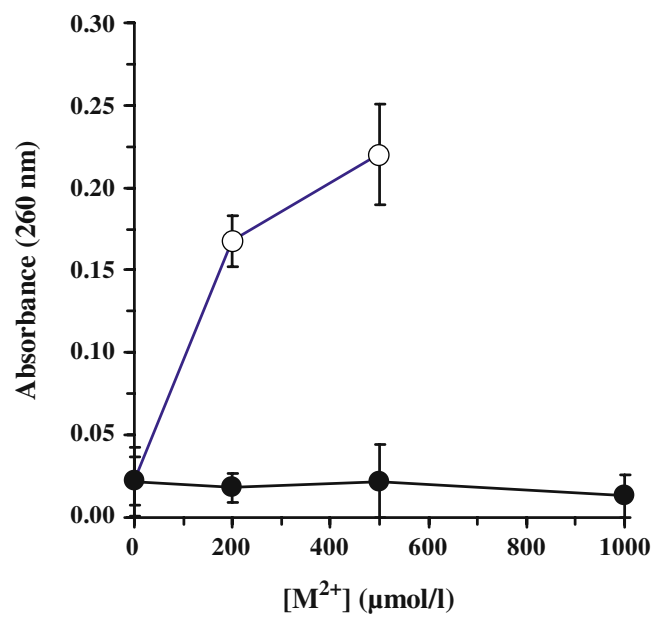

Fig. 1 Leakage of $\mathrm{UV}_{260^{-}}$-absorbing cellular components from $S$. cerevisiae NCYC $1214 ; 1 \times 10^{7}$ cells $/ \mathrm{ml}$ was suspended in $10 \mathrm{mmol} /$ 1 MES $\mathrm{pH}$ buffer $(\mathrm{pH} 6.0)$ with $2 \%(w / v)$ of glucose. Cells were treated with different concentrations of $\mathrm{Pb}\left(\mathrm{NO}_{3}\right)_{2}$ (filled circles) or $\mathrm{CuCl}_{2}$ (empty circles) (control ion), during $30 \mathrm{~min}$. UV-absorbing compounds were determined in the filtrates. Each point represents the mean of three independent experiments performed in duplicate; standard deviations are presented $(n=6)$

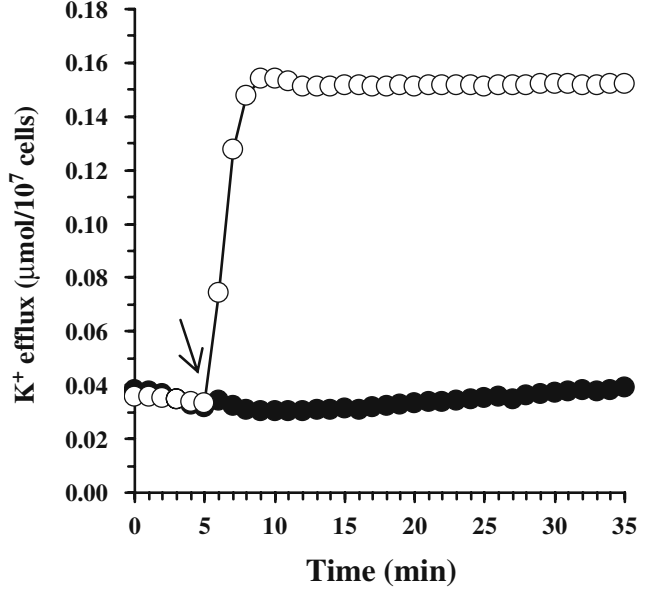

Fig. $2 \mathrm{~K}^{+}$efflux from $S$. cerevisiae NCYC 1214, in response to metals; $1 \times 10^{7}$ cells $/ \mathrm{ml}$ was suspended in $10 \mathrm{mmol} / 1 \mathrm{MES} \mathrm{pH}$ buffer (pH 6.0) with $2 \%(w / v)$ of glucose. At the time point indicated by the arrow, $1,000 \mu \mathrm{mol} / 1 \mathrm{~Pb}\left(\mathrm{NO}_{3}\right)_{2}$ (filled circles) or $200 \mu \mathrm{mol} / 1 \mathrm{CuCl}_{2}$ (empty circles) (control ion) were added. The efflux of potassium from cells was measured using a $\mathrm{K}^{+}$-selective electrode. This is a typical example of an experiment performed three times

higher than $760 \mathrm{Da}$ (Klis et al. 2002). In practice, it means that cell membrane is the first structure which is in contact with most of the chemical species. Thus, first of all, the impact of $\mathrm{Pb}$ on yeast cell membrane integrity was evaluated. For this purpose, two independent techniques were used: measurement of $\mathrm{UV}_{260}$-absorbing compounds and intracellular $\mathrm{K}^{+}$efflux. As it can be seen in Fig. 1, no appreciable amount of $\mathrm{UV}_{260}$-absorbing compounds was released by yeast cells during the 30 min of $\mathrm{Pb}$ exposition

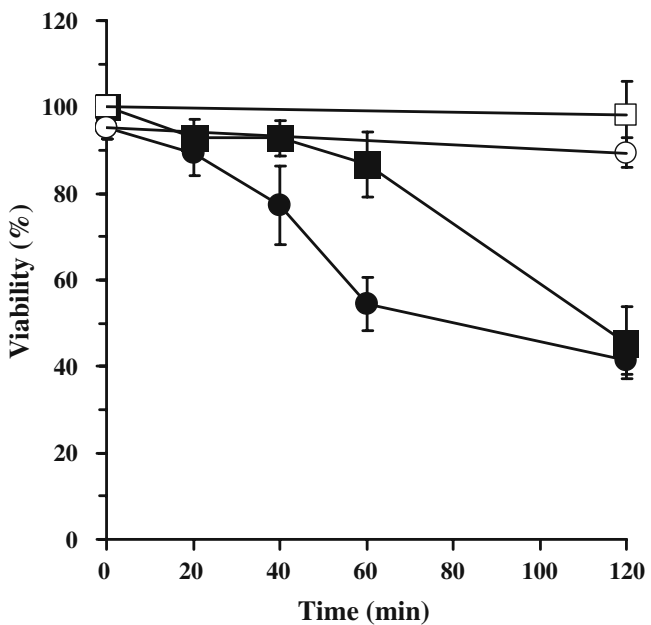

Fig. 3 Viability of $S$. cerevisiae NCYC 1214 during incubation with $1,000 \mu \mathrm{mol} / 1 \mathrm{~Pb}\left(\mathrm{NO}_{3}\right)_{2} ; 1 \times 10^{7} \mathrm{cells} / \mathrm{ml}$ was suspended in $10 \mathrm{mmol} /$ 1 MES $\mathrm{pH}$ buffer $(\mathrm{pH} 6.0)$ with $2 \%(w / v)$ of glucose. Viability was estimated by colony-forming units (c.f.u.) counting (filled squares) or by fluorescence microscopy after staining with FUN-1 (filled circles). Control: cells incubated in the buffer in the absence of $\mathrm{Pb}$ (open symbols). Each point represents the mean of three independent experiments performed in duplicate; standard deviations are presented $(n=6)$ 
Fig. 4 Cells of $S$. cerevisiae NCYC 1214 stained with FUN1. Fluorescence micrographs (a, c, and e); phase contrast micrographs of the same cells (b, d, and f). Micrographs of cells before being exposed (a and $\mathbf{b}$ ) or after being exposed, during $2 \mathrm{~h}$ to $1,000 \mu \mathrm{mol} / 1 \mathrm{~Pb}\left(\mathrm{NO}_{3}\right)_{2}$ (c-f). Arrow 1: metabolic active cells with CIVS; arrow 2: metabolic inactive cells (cells without CIVS)
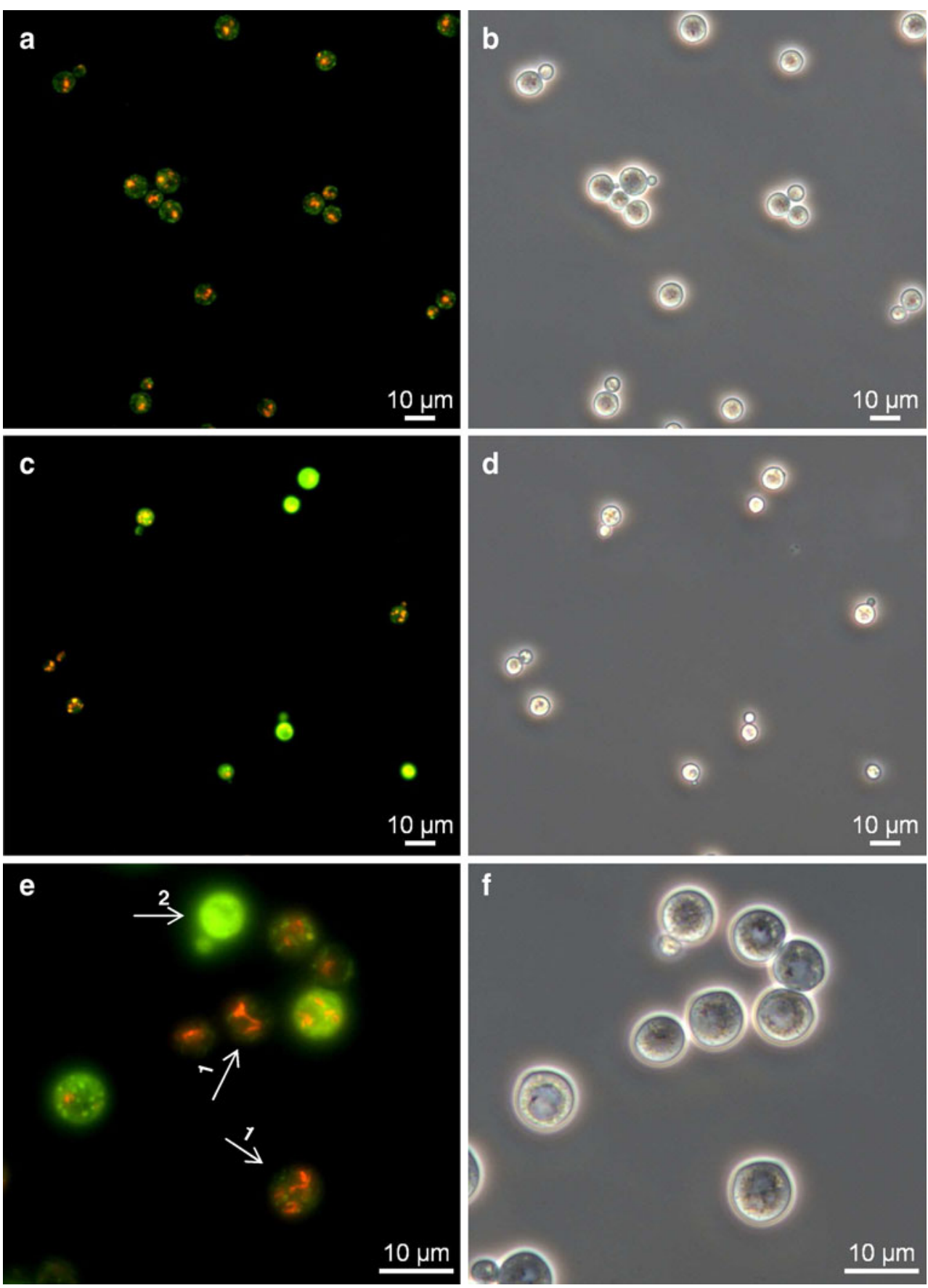

concentrations up to $1,000 \mu \mathrm{mol} / \mathrm{l}$. Similarly, no induction of the efflux of $\mathrm{K}+$ was observed (Fig. 2); for $\mathrm{K}^{+}$efflux, results for 0 (water addition) and $500 \mu \mathrm{mol} / \mathrm{l} \mathrm{Pb}$ were not shown for pictorial clarity. In both experiments, $\mathrm{Cu}$ was used as positive control; in this case, a strong disruption of cell membrane integrity which provoked a fast (within 1$2 \min )^{+}$efflux (Fig. 2) and the release of $\mathrm{UV}_{260^{-}}$ absorbing compounds was observed (Fig. 1). These results strongly suggest that yeast cell membrane is not the first target of $\mathrm{Pb}$ toxic effects.
Action on yeast cell metabolism and proliferation capacity

Subsequently, the effect of $\mathrm{Pb}$ on yeast metabolic activity was assessed using FUN-1 and compared with the cell proliferation capacity evaluated by classical spread technique (colony-forming units (c.f.u.) counting). The loss of cells viability provoked by the presence of $1,000 \mu \mathrm{mol} /$ $1 \mathrm{~Pb}^{2+}$, evaluated by the staining of yeast cells with FUN-1 probe, follows the same pattern of the loss of cell proliferation capacity (Fig. 3). 
Metabolic active yeast cells are able to process and concentrate FUN-1 within the vacuoles, originating orangered cylindrical intravacuolar structures (CIVS) (Fig. 4a, c, and e); on the other hand, non-active cells, with intact membrane, show a diffuse green cytoplasmatic fluorescence (Fig. 4c, e) (Millard et al. 1997). Before Pb treatment, more than $95 \%$ of cells display CIVS (Fig. 3 and $4 a, b$ ). $\mathrm{Pb}$ interferes with FUN-1 intracellular processing (Fig. 3 and $4 \mathrm{c}, \mathrm{e})$. This interference seems to be an early response to $\mathrm{Pb}$ toxic effects. After $1 \mathrm{~h}$ of yeast cells exposition to $\mathrm{Pb}, 40 \%$ of cells lost the ability to process the fluorochrome FUN-1, but retained their proliferation capacity. Nevertheless, a similar loss of $55 \%$ of viability was observed by the two techniques after $2 \mathrm{~h}$ of contact with $\mathrm{Pb}$ (Fig. 3).

The requirement of protein synthesis on the loss of cell proliferation capacity $\mathrm{Pb}$-induced was evaluated by exposing the yeast cells simultaneously to the action of several $\mathrm{Pb}$ concentrations and $25 \mu \mathrm{g} / \mathrm{ml}$ of Cyh. Control experiments have shown that $25 \mu \mathrm{g} / \mathrm{ml}$ Cyh was not toxic to yeast cells (data not shown). The presence of Cyh reduces the loss of cell viability (accessed by c.f.u. counting), induced by 750 and $1,000 \mu \mathrm{mol} / 1 \mathrm{~Pb}$ (Fig. 5). These results indicate that the loss of viability induced by $\mathrm{Pb}$ is dependent of protein synthesis.

\section{Discussion}

In the last two decades, a considerable research effort has been done related to the interaction of $S$. cerevisiae yeast cells with

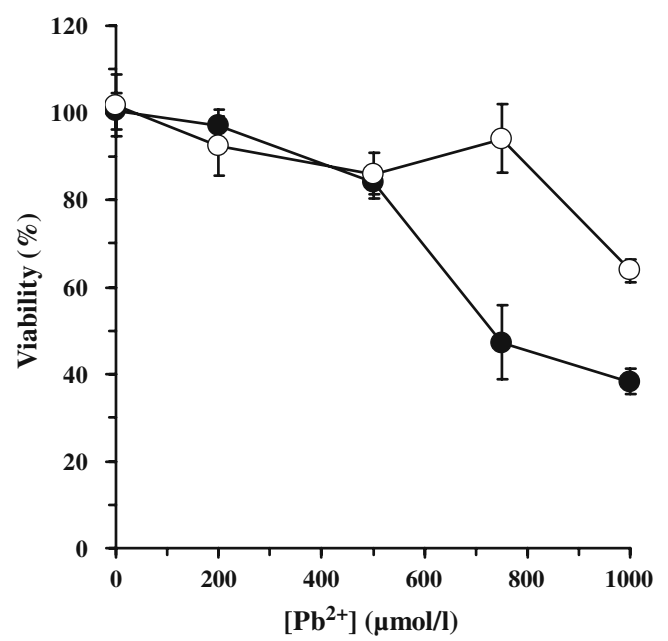

Fig. 5 Influence of cycloheximide in lead-induced toxicity on $S$. cerevisiae NCYC 1214. Cells were incubated with different $\mathrm{Pb}^{2+}$ concentrations, under the conditions described in Fig. 1, in the absence (filled circles) or in the presence (empty circles) of $25 \mu \mathrm{g} / \mathrm{ml}$ of cycloheximide. Viability was estimated by the spread plate technique, as described in "Materials and methods". Each point represents the mean of three independent experiments performed in duplicate; standard deviations are presented $(n=6)$ heavy metals, particularly those aspects associated with its use in metals removal (Wang and Chen 2006).

It is well known that yeast cell membrane is the initial site of the toxic action of several metals like $\mathrm{Cd}, \mathrm{Co}, \mathrm{Cu}$, Hg and Zn (Norris and Kelly 1977; Kuypers and Roomans 1979; Gadd and Mowll 1983; Mowll and Gadd 1983; Soares et al. 2003). In the present work, the action of $\mathrm{Pb}$ on yeast cell membrane was evaluated by the release of UVabsorbing compounds and $\mathrm{K}^{+}$efflux. UV-absorbing compounds are mainly composed by nitrogenous compounds derived from nucleotides and related molecules (Delisle and Phaff 1961). It was shown that the injury of cell membrane by heavy metals $(\mathrm{Cd}, \mathrm{Co}, \mathrm{Cu}$ and $\mathrm{Zn})$ induce the leakage of $\mathrm{UV}_{260}$-absorbing compounds (Joho et al. 1984; Ohsumi et al. 1988; Brady and Duncan 1994; Soares et al. 2002). As a positive control, $\mathrm{Cu}$ was used to induce damage on yeast membrane. As a consequence of plasma membrane permeabilization, there is a rapid leakage of $\mathrm{UV}_{260}$-absorbing compounds. This is a very sensitive index of metal toxicity (Soares et al. 2003). In the present work, the exposition of yeast cells up to $1,000 \mu \mathrm{mol} / \mathrm{l} \mathrm{Pb}$, during $30 \mathrm{~min}$, did not induce the leakage of $\mathrm{UV}_{260}$-absorbing compounds.

Metal accumulation in yeast cells is often accompanied by $\mathrm{K}^{+}$efflux in an approximate ratio $1 \mathrm{Metal}^{2+}$ (in) $/ 2 \mathrm{~K}^{+}$(out), in order to maintain the ionic balance (Norris and Kelly 1977; Borst-Pauwels 1981; De Rome and Gadd 1987). Nevertheless, $\mathrm{K}^{+}$efflux can occur in a no-stoichiometric relationship, as a consequence of the disruption of yeast cell membrane integrity of $S$. cerevisiae, due to the action of heavy metals, such as Cu Cd, Co and Zn (Norris and Kelly 1977; Gadd and Mowll 1983; Mowll and Gadd 1983; Ohsumi et al. 1988; Brady and Duncan 1994). In the present study, the exposition of yeast cells up to $1,000 \mu \mathrm{mol} / \mathrm{Pb}$, during $30 \mathrm{~min}$, did not provoke a $\mathrm{K}^{+}$efflux. $\mathrm{Cu}$ was also used as a positive control. Together, the data obtained by two independent techniques evidenced that yeast plasma membrane is not the immediate and primary target of $\mathrm{Pb}$ toxicity in $S$. cerevisiae.

When metabolic active cells are stained with FUN-1, red-orange CIVS could be observed (Fig. 4e); the mechanism of FUN-1 processing seems to involve the reaction with reduced glutathione (GSH), in cytosol, in an enzymemediated process, originating the formation of glutathione conjugates. After the biochemical modification, the dye is transported and sequestered in the vacuole as CIVS (Millard et al. 1997). The exposition of yeast cells to $1,000 \mu \mathrm{mol} / \mathrm{l} \mathrm{Pb}$, during $1 \mathrm{~h}$, hindered the CIVS formation (Fig. 3); however, these cells retained their ability to reproduce after being plated on YEPD agar medium without $\mathrm{Pb}$, which ultimately define the cell viability (Fig. 3). Since the decrease in the ability to process FUN-1 preceded the loss of replication competence, these results suggest that intracellular FUN-1 processing gives an early indication of toxicity induced by $\mathrm{Pb}$. 
It is described the involvement of GSH and vacuole in the detoxification of several metals. The sequestration of metals in the vacuole seems to be a form of cytosolic regulation of essential ions or a mechanism of the detoxification; examples of metals that are sequestered in the vacuole are $\mathrm{Co}, \mathrm{Mn}, \mathrm{Ni}$ and Zn (Gadd 1993; Ramsay and Gadd 1997). In the case of toxic metals, the compartmentalisation in the vacuole prevents its presence in the cytosol and the consequent toxic effects. GSH is also involved in the detoxification of several metals, such as Cd and Se (Gharieb and Gadd 2004), most likely by complexation; as a consequence, there is a decreasing of metals availability for toxic interactions, such as the inhibition of thiol-containing enzymes. Taking into account the mechanism underlying the cell staining with FUN-1 probe, the inhibition of CIVS formation in $\mathrm{Pb}$ exposed cells may suggest that one of them or both mechanisms of defence reported above could be implicated in $\mathrm{Pb}$ detoxification.

After $2 \mathrm{~h}$ of $\mathrm{Pb}$ exposition, the percentage of cell population unable to process FUN-1 fluorochrome was in agreement with the percentage of cells that loss proliferation capacity; these results evidence a more deep toxic effect of $\mathrm{Pb}$ on yeast cells.

The mechanism of $\mathrm{Pb}$-induced toxicity seems to involve protein synthesis. This is supported by the fact that the incubation of cells in the presence of Cyh (in eukaryotes, Cyh inhibits cytoplasmatic protein synthesis at the ribosomal level) (Kuo et al. 1973) attenuated the toxic effect (assessed by c.f.u. counting) induced by high $\mathrm{Pb}$ concentrations. The reduction of $\mathrm{Pb}$ bioavailability due to its complexation by Cyh cannot be excluded; however, taken into account the molar ratios $([\mathrm{Cyh}] /[\mathrm{Pb}])$ used $(0.12$ and 0.089 , for 750 and $1,000 \mu \mathrm{mol} / 1 \mathrm{~Pb}$ concentrations, respectively), the alleviation of $\mathrm{Pb}$ toxic effects cannot be attributed to $\mathrm{Pb}$ complexation. In the limit (if all the $\mathrm{Pb}$ is complexed with $\mathrm{Cyh}$ ), a small decrease of $\mathrm{Pb}$ availability ( $12 \%$ and $9 \%$ for 750 and $1,000 \mu \mathrm{mol} / 1$, respectively) could be provoked; this means that the presence of Cyh would reduce $\mathrm{Pb}$ concentrations from 750 and 1,000 to 660 and $911 \mu \mathrm{mol} / \mathrm{l}$, respectively. For these concentrations, in the absence of Cyh, a viability of $62 \%$ and $44 \%$, respectively, is predicted (Fig. 5). These results are markedly different from those obtained in the presence of Cyh (94\% and 64\%, respectively).

In conclusion, the results presented in this study evidence that plasma membrane is not the immediate and primary target of $\mathrm{Pb}$ toxicity in $S$. cerevisiae. The loss of cell metabolic activity (evaluated by the ability to process FUN-1) seems to be an early indicator of $\mathrm{Pb}$ toxicity. A more prolonged contact $(2 \mathrm{~h})$ of yeast cells with $\mathrm{Pb}$ provokes a marked $(>50 \%)$ loss of yeast cell metabolic activity and proliferation capacity through a mechanism which requires protein synthesis.
Acknowledgment Maarten Van der Heggen (KaHo St.-Lieven, Ghent, Belgium) wishes to thank Dr. Luc De Cooman for the opportunity to participate in the ERASMUS bilateral agreement program between his school and ISEP (Portugal).

\section{References}

ATSDR (2007) Toxicological profile for lead. Agency for Toxic Substances and Disease Registry (ATSDR). U.S. Department of Health and Human Services-Public Health Service

Borst-Pauwels GWFH (1981) Ion transport in yeast. Biochim Biophys Acta 650:88-127

Brady D, Duncan JR (1994) Cation loss during accumulation of heavy metal cations by Saccharomyces cerevisiae. Biotechnol Lett 16:543-548

Chen C, Wang JL (2007) Response of Saccharomyces cerevisiae to lead ion stress. Appl Microbiol Biotechnol 74:683-687

De Rome L, Gadd GM (1987) Measurement of copper uptake in Saccharomyces cerevisiae using a $\mathrm{Cu}^{2+}$-selective electrode. FEMS Microbiol Lett 43:283-287

Delisle AL, Phaff HJ (1961) The release of nitrogenous substances by brewer's yeast. Proc Am Soc Brew Chem 103-118

Gadd GM (1993) Interaction of fungi with toxic metals. New Phytologist 124:25-60

Gadd GM, Mowll JL (1983) The relationship between cadmium uptake, potassium release and viability in Saccharomyces cerevisiae. FEMS Microbiol Lett 16:45-48

Gharieb MM, Gadd GM (2004) Role of glutathione in detoxification of metal(loid)s by Saccharomyces cerevisiae. Biometals 17:183188

Gilfillan SC (1965) Lead poisoning and the fall of Rome. J Occup Med 7:53-60

Goffeau A, Barrell BG, Bussey H, Davis RW, Dujon B, Feldmann H, Galibert F, Hoheisel JD, Jacq C, Johnston M, Louis EJ, Mewes HW, Murakami Y, Philippsen P, Tettelin H, Oliver SG (1996) Life with 6000 genes. Science 274:546-567

Joho M, Ishibe A, Murayama T (1984) The injurious effect of heavy metal ions on the cell membrane in Saccharomyces cerevisiae. Trans Mycol Soc Japan 25:485-488

Klis FM, Mol P, Hellingwerf K, Brul S (2002) Dynamics of cell wall structure in Saccharomyces cerevisiae. FEMS Microbiol Rev 26:239-256

Kuo SC, Cano FR, Lampen JO (1973) Lomofungin, an inhibitor of ribonucleic acid synthesis in yeast protoplasts: its effect on enzyme formation. Antimicrob Agents Chemother 3:716-722

Kuypers GAJ, Roomans GM (1979) Mercury induced loss of $\mathrm{K}^{+}$from yeast cells investigated by electron-probe X-ray-microanalysis. J Gen Microbiol 115:13-18

Millard PJ, Roth BL, Thi HPT, Yue ST, Haugland RP (1997) Development of the FUN-1 family of fluorescent probes for vacuole labeling and viability testing of yeasts. Appl Environ Microbiol 63:2897-2905

Mowll JL, Gadd GM (1983) Zinc uptake and toxicity in the yeasts Sporobolomyces roseus and Saccharomyces cerevisiae. J Gen Microbiol 129:3421-3425

Norris PR, Kelly DP (1977) Accumulation of cadmium and cobalt by Saccharomyces cerevisiae. J Gen Microbiol 99:317-324

Ohsumi Y, Kitamoto K, Anraku Y (1988) Changes induced in the permeability barrier of the yeast plasma membrane by cupric ion. J Bacteriol 170:2676-2682

Ramsay LM, Gadd GM (1997) Mutants of Saccharomyces cerevisiae defective in vacuolar function confirm a role for the vacuole in 
toxic metal ion detoxification. FEMS Microbiol Lett 152:293298

Soares HMVM, Conde PCFL, Almeida AAN, Vasconcelos MTSD (1999a) Evaluation of $n$-substituted aminosulfonic acid $\mathrm{pH}$ buffers with a morpholinic ring for cadmium and lead speciation studies by electroanalytical techniques. Anal Chim Acta 394:325-335

Soares HMVM, Pinho SC, Barros MGRTM (1999b) Influence of Nsubstituted aminosulfonic acids with a morpholinic ring $\mathrm{pH}$ buffers on the redox processes of copper or zinc ions: a contribution to speciation studies. Electroanalysis 11:1312-1317

Soares EV, Duarte A, Soares H (2000) Study of the suitability of 2-(Nmorpholino) ethanesulfonic acid $\mathrm{pH}$ buffer for heavy metals accumulation studies using Saccharomyces cerevisiae. Chem Speciation Bioavail 12:59-65
Soares EV, Duarte APSR, Boaventura RA, Soares HMVM (2002) Viability and release of complexing compounds during accumulation of heavy metals by a brewer's yeast. Appl Microbiol Biotechnol 58:836-841

Soares EV, Hebbelinck K, Soares HMVM (2003) Toxic effects caused by heavy metals in the yeast Saccharomyces cerevisiae: a comparative study. Can J Microbiol 49:336-343

Suh JH, Yun JW, Kim DS (1999) Cation $\left(\mathrm{K}^{+}, \mathrm{Mg}^{2+}, \mathrm{Ca}^{2+}\right)$ exchange in $\mathrm{Pb}^{2+}$ accumulation by Saccharomyces cerevisiae. Bioprocess Eng 21:383-387

US-EPA (2006) National recommended water quality criteria. United States Environmental Protection Agency EPA. Office of Water, Science and Technology (4304T), Washington, DC

Wang J, Chen C (2006) Biosorption of heavy metals by Saccharomyces cerevisiae: a review. Biotechnol Adv 24:427-451 